\title{
Em torno de "Todesfuge" de Paul Celan
}

\author{
[On "Todesfuge" by Paul Celan] \\ http://dx.doi.org/10.11606/1982-88372237357
}

\begin{abstract}
Maria Silvia Cintra Martins ${ }^{1}$
"Dichter ist, wer menschlich spricht"

"Verouiller la langue pour empêcher le mensonge. Il vaut mieux bégayer que rimer"
\end{abstract}

(Paul Celan)

\begin{abstract}
I explore, in this paper, the poem "Todesfuge", by the German poet and translator Paul Celan, and based on it I make connections with some conceptions present in Henri Meschonnic's work as a French linguist, poet and translator. I explore the themes of Ethics and Esthetics, so relevant for both authors. In the course of the analysis of "Todesfuge", I particularly call the attention to the way its title has been translated into Portuguese, as well as to the consequences of such choices.
\end{abstract}

Keywords: dialogue; Todesfuge; Poetics; orality.

Resumo: Exploro neste trabalho o poema "Todesfuge", do poeta e tradutor alemão Paul Celan, e, a partir dele, teço relações com concepções advindas do ideário do linguista, poeta e tradutor francês Henri Meschonnic. As temáticas da Ética e da Estética, caras aos dois autores, fazem-se presentes. No decorrer da análise de "Todesfuge", chamo a atenção, particularmente, para a forma da tradução de seu título em língua portuguesa, assim como para as eventuais decorrências dessas escolhas.

Palavras-chave: diálogo; Todesfuge; Poética; oralidade.

\section{Introdução: uma escrita em diálogo com o Outro}

Meu conhecimento a respeito da obra poética do escritor alemão Paul Celan ainda era bastante restrito à época em que comecei a me dedicar ao estudo da obra do linguista, poeta e tradutor francês Henri Meschonnic, e foi através das referências deste à obra daquele que fui me dando conta da forma com que ambas as obras se relacionam e se explicam mutuamente, ou melhor, se fazem entender com mais facilidade à luz uma da outra.

\footnotetext{
${ }^{1}$ Universidade Federal de São Carlos, Rodovia Washington Luís, km 235, São Carlos, SP, 13565-905, Brasil. E-mail: msilviamart@ gmail.com. ORCID: 0000-0003-3911-418X
} 
Diante da vasta obra de Celan, escolhi seu poema mais conhecido e mais traduzido para nossa língua, "Todesfuge”, para este trabalho. Quanto à escrita de Meschonnic, não fiz escolha prévia. Deixei que suas ideias comparecessem de acordo com a leitura do poema alemão e o desafio que este impõe às suas diversas traduções. Assim, algumas das concepções teóricas do linguista francês estarão divididas em subtópicos, mas voltarão a comparecer no decorrer de nossas reflexões. O conceito de oralidade, tão caro ao teórico francês, será retomado diversas vezes por se apresentar como conceito-chave que pode nos trazer luzes para o entendimento de outras questões, como a da Ética por exemplo.

Lembremo-nos que estamos diante de dois escritores que têm apresentado dificuldades à compreensão de suas ideias. Celan apontado como obscuro e hermético, Meschonnic, como portador de ideias confusas e mal explicitadas. Ambos possuem ascendência judaica, Celan nascido em 1920 e Meschonnic em 1932. Celan suicidou-se no rio Sena em 1970, e Meschonnic faleceu em 2009.

Para iniciar nossas divagações, proponho partirmos do pressuposto de Celan (1996a) de tonalidade ética, de que falamos para ("zu”) e contra ("gegen”) o outro, e do pressuposto de Meschonnic de que não importa tanto saber de onde falamos, mas sim para quem falamos. Meschonnic (2008) faz referência à postulação de Celan, particularmente na defesa da oralidade como forma específica da linguagem poética, e em sua explicação (nem sempre tida como suficientemente clara) de que o oral não residiria no relato ("récit"), e, sim, no recitativo ("récitatif"), enquanto apropriação da linguagem por parte de um "eu" que se defronta e se confronta diante de um outro.

Esta é, aliás, uma característica central de "Todesfuge”, e quem sabe até mesmo um ponto importante para dissipar ou amenizar a polêmica (de teor ético) que foi gerada em função do célebre "dictum" de Theodor Adorno, renomado filósofo da Escola de Frankfurt, para quem não caberia a estetização de algo tão trágico quanto o holocausto alemão. É fato que, diante da polêmica existente em torno do poema, Celan excluiu “Todesfuge” de suas leituras em público a partir dos anos de 1960. Note-se, no entanto, que enquanto poema declamado seus versos já se iniciariam em tonalidade vocativa, uma vez que o "sie", que por escrito pode assumir o papel da terceira pessoa, daquele de quem se fala, declamado pode ser entendido como "Sie", fazendo com que as primeiras palavras, "Schwarze Milch der Frühe" adquiram ares de vocativo, ou seja, de interpelação do outro. É fato que nas traduções de João Barrento e de Renato Suttana para 
a língua portuguesa, a sequência "trinken sie" é traduzida, respectivamente, como "bebemo-lo" e como "bebemos-te".

O poema começaria na linha de leitura proposta por "bebemos-te", pela interpelação do leite da madrugada, para passar, em seguida, à interpelação do outro (“autrui"). Trago estas palavras do filósofo francês Emmanuel Levinas para a melhor compreensão da implicação do uso do vocativo:

A pretensão de saber e de alcançar o Outro ["l'Autre"] realiza-se dentro da relação com outrem ["l'autrui"], a qual se encontra imersa na relação da linguagem, em que o essencial é a interpelação, o vocativo. O outro se mantém e se confirma em sua heterogeneidade à medida que o interpelamos, seja para lhe dizer que não podemos falar com ele, para colocá-lo como doente, para lhe anunciar sua condenação à morte; enquanto é agarrado, ferido, violentado, ele é "respeitado". O invocado não é aquilo que compreendo: não pertence a uma subcategoria. É aquele com quem falo - ele não tem uma referência a si, não tem uma quididade. Mas a estrutura formal da interpelação deve ser desenvolvida (LEVINAS 2017: 65, tradução minha).

Seguindo essa linha de pensamento, podemos concluir que Celan não relata o genocídio: ele desafia a nós, leitores e tradutores, diante de uma leitura-ferida (DERRIDA 1986), já que, ao sermos colocados como o Outro a quem se dirige com uma denúncia, deixa-nos na posição de testemunhas em caráter irrevogável: "O poema quer ir ao encontro de um Outro, precisa desse Outro, de um Interlocutor. Procura-o e oferece-selhe”. E, ainda: "Cada coisa, cada indivíduo é, para o poema que se dirige para o Outro, figura desse Outro" (CELAN 1996a: 57).

Somos, é fato, tratados em parte e simultaneamente como "tu" e como "nós": nós que bebemos do leite negro da aurora ("Schwarze Milch der Frühe wir trinken sie abends"), nós que cavamos um túmulo ("wir schaufeln ein Grab in den Lüften da liegt man nicht eng"), mas que também somos "tu", pois somos um com o eu-lírico (com ele fazemos o "nós" e formamos coro), e com ele nos dirigimos a Margarete e a Sulamith/ Sulamita (“dein goldenes Haar Margarete/ Dein aschenes Haar Sulamith”); com ele nós tratamos de "tu" o leite negro da madrugada. Nós os tuteamos ("Schwarze Milch der Frühe wir trinken dich nachts/ wir trinken dich morgens und mittags wir trinken dich abends/ wir trinken und trinken"), e juntos também somos "tu": o "tu" de Margarete (nome que implicitamente nos remete à Gretchen, do "Fausto"), o "tu" de Sulamith (denominação que nos aproxima dos judeus) (CELAN 1996b: 14).

Tornamo-nos, no entanto, “ihr”, ou seja, "vós” para o homem de olhos azuis, para o algoz, de quem recebemos ordens ("Er ruft stecht tiefer ins Erdreich ihr einen ihr andern 
singet und spielt"). A menos, é claro, que queiramos nos colocar do seu lado, na qualidade de seus cães, de seus mastins, quem sabe.

Nesta introdução, ainda vale apontar que, se encontro reverberações entre as palavras que nos lançam Celan e Meschonnic, não há como negligenciar, em ambos, a presença de Stéphane Mallarmé, a quem farei referência adiante, a partir da própria escrita polifônica de "Todesfuge", que pode nos lembrar da orquestração das vozes de "Um lance de dados" ("Un coup de dés").

Meschonnic refere-se muitas vezes à escrita de Mallarmé, particularmente para apontar uma leitura da obra do eminente escritor francês que não enfatize, como tem sido frequentemente o caso, apenas seu tom construtivo ou aparentemente destituído de significado, já que o sentido se construiria na própria rítmica que o poema propõe, e não dentro de uma eventual separação entre significante e significado. Também o faz para nos lembrar da afirmação do poeta francês do final do século XIX sobre o poder sugestivo de todo poema; esta seria a vocação do poético: sugerir.

É fato, ainda, que, em “O Meridiano”, publicação decorrente de palestra proferida quando da recepção do prêmio George Büchner, Celan (1996a) enfatiza exatamente este ponto, o da sugestão, à medida que convida os presentes a refletirem sobre o que é a arte, o que é o poema.

\section{Todesfuge}

O poema "Todesfuge” foi finalizado por volta de 1945, e conta com diversas propostas tradutórias para a língua portuguesa, entre as quais menciono as dos seguintes tradutores: Modesto Carone, João Barrento, Renato Suttana, Cláudia Cavalcanti, Jorge de Sena, Leandro Konder, Nelson Ascher e Maurício Cardozo. Tematizando o genocídio dos judeus durante a segunda guerra mundial, o poema foi publicado na Alemanha pela primeira vez em 1948. Notamos que as dificuldades de tradução para a língua portuguesa se iniciam com o título do poema. Carone o traduz por "Fuga da morte", assim como a maior parte dos tradutores mencionados. Fogem a essa opção apenas Nelson Ascher, com "Fuga Fúnebre"; Maurício Cardozo, com o neologismo "Funesfuga"; e Cláudia Cavalcanti, com "Fuga sobre a morte", ao querer, talvez, dar destaque ao estilo musical 
da fuga enquanto composição polifônica em que um tema principal é assumido e repetido diversas vezes, repetição que, de fato, se dá no poema em sequências como "Schwarze Milch der Frühe wir trinken...", entre outras.

Haja vista que o alemão possui palavras diferentes para o que entendemos por "fuga" em língua portuguesa: "Fuge", que aparece no título do poema, remete à fuga enquanto estilo musical; "Flucht", por sua vez, relaciona-se com "fliehen", com o sentido de "fugir". Vale lembrar ainda a incerteza da etimologia do termo "fuga" enquanto estilo musical, conforme o próprio Mário de Andrade (1944) já nos alertava em sua "Pequena História da Música". O termo "fuga", em latim, estaria relacionado tanto com "fugere" ("fugir"), como com "fugare" ("caçar"), e a denominação da composição musical em si, explorada particularmente por Bach, em que um tema é repetido por vozes que entram sucessivamente provocando-lhe variações, acaba por nos remeter, por associação, na língua portuguesa, à ideia de fuga, no sentido de esquiva, mesmo que não lhe conheçamos a verdadeira etimologia.

Cabe indicar aqui o alerta de Meschonnic, quando, ao pensar particularmente na escritura e na tradução, nos lembra que o sentido das palavras reside na sua força, ou seja, no que elas fazem e provocam, e não na etimologia ou, mesmo, num eventual efeito de discurso: "Pois só há sentido na linguagem. Mas pode-se juntar força ao sentido, algo que o sentido em si não contém” (MESCHONNIC 2000: 12, tradução minha). Meschonnic insistirá nessa questão no decorrer de sua obra volumosa, já desde o clássico "Critique du rithme” (1982), em que a junção entre Ética, Política e Estética se faz presente, e o ritmo comparece como fio condutor entre o Sujeito e a História.

Aproveito para lembrar o quanto essa questão em que o linguista francês se detém está presente ou se reapresenta em diferentes momentos e contextos históricos de reflexão sobre a linguagem e sobre a tradução. O próprio Meschonnic, em suas obras, nos remete aos pensamentos de Espinosa e de Humboldt para defender a presença da força na linguagem. Não faz menção a Goethe, mas, como é sabido, já na Primeira Parte da tragédia do poeta alemão flagramos um Fausto pensativo, às voltas com a interpretação do Evangelho do apóstolo João, a refletir sobre qual seria a tradução mais adequada para “Am Anfang war das Wort", "Era no início o Verbo" (“das Wort”), ou era "o Sentido" (“der Sinn”), ou seria, talvez, “a Força", “a Energia” (“die Kraft”)? Conclui: "Und 
schreibe getrost: Im Anfang war die Tat!" - "E escrevo em paz: Era no início a Ação!" (GoETHE, 1981: 68).

Palavras que podemos fazer ecoar naquelas de Meschonnic (2006: 66), quando aproxima a questão própria da oralidade (e inversamente) da histeria: "Eis o que a oralidade partilha, de maneira surpreendente, com a histeria: não ser mais um dizer, nem um dito, mas um fazer". A inversão é provocada na medida em que, segundo Meschonnic:

Talvez se possa dizer que há oralidade quando é a linguagem que se torna histérica. Não o locutor. A oralidade intervindo como uma contra-histeria, uma forma de histeria que colocaria o corpo na linguagem. O máximo possível do corpo e de sua energia. Como ritmo. O ritmo como forma-sujeito. Enquanto, inversamente, a histeria coloca a linguagem no corpo. E o faz mimetizá-la (MESCHONNIC 2006: 65).

Pensando-se que o sentido não se encontra em palavras isoladas, mas na força que as envolve conjuntamente, o fato é que, uma vez que a acepção musical não nos é muito corrente, um título como "Fuga da morte" nos remete, em princípio, à noção da esquiva em relação à morte, em função de ideias complementares que estariam em jogo dentro da sequência sintagmática em que se encontra. Até mesmo porque a morte é algo que, por natureza, nos provoca relação de aversão, e fugimos de algo que queremos evitar. É assim que mesmo a proposta tradutória de Cavalcanti não nos permite escapar desse viés, pois haveria como que um empuxe provocado pelo léxico "fuga", de tal modo que "Fuga sobre a morte", em lugar de nos fazer pensar numa eventual modalidade musical que tematizasse a morte, nos remete a um movimento de pairar sobre a morte, tentando livrarse dela, algo que pode se confirmar com a possibilidade que o poema nos contempla, de se "cavar um túmulo no ar", em verso que se repete: "wir schaufeln ein Grab in den Lüften da liegt man nicht eng" (CELAN 1996b: 14).

Neste trabalho, entretanto, pretendo me deter especialmente a aspectos referentes ao ritmo, à força da linguagem e à estruturação das palavras no estilo das frases musicais no estilo fugal. Assim, se me refiro aqui ao título e a algumas palavras isoladas, isto se deve, apenas, ao caráter panrítmico, i.e., à semântica serial que o próprio título comporta, ao dar abertura e anunciar o que está por vir.

Enfatizo, de toda forma, que se trata da estruturação das palavras, conforme coloquei acima, à moda das frases musicais no estilo fugal, e não - outro ponto com o qual concordam Meschonnic e Celan - de um eventual ritmo ou princípio musical que 
seria transposto ao poema, já que o ritmo com que trabalha a poesia difere do ritmo musical no entendimento de ambos.

\section{$3 \bigcirc$ combate contra o signo: a defesa da panrítmica e da subjetivação da linguagem}

Nesse ponto, é interessante retomar e problematizar o embate meschonniciano em torno do signo, i.e., seu combate ao signo e ao que denomina semiotização, ou seja, a abordagem dicotômica da linguagem em forma e conteúdo, e sua defesa do semântico e do discursivo que redunda na panrítmica e na semântica serial. O sentido não residiria no signo, mas na panrítmica gerada discursivamente. Interessante lembrar que esse combate é dirigido à leitura estruturalista de Saussure, e não à epistemologia saussureana em si, que não conteria, por princípio, um viés estruturalista ou dicotomizante. Nessa medida, o grande combate de Meschonnic se faz contra as dicotomizações e, mais particularmente, contra a separação entre significante e significado, lembrando-nos que não se trataria apenas de uma exigência própria ao poético, mas inerente à linguagem em geral, construída de forma mais intensa e aparente na escrita. É assim que Meschonnic afirma:

A poética mostra que há, na linguagem, ao mesmo tempo o descontínuo do signo, das palavras, e das línguas, que é conhecido, mas também um contínuo que o conhecido impede de conhecer. $\mathrm{O}$ signo produziu um saber que cria sua própria ignorância e impede de vê-la (MESCHONNIC 2005: 252).

Se voltamos à nossa questão em torno do título "Todesfuge", o que notamos, então, é que há algo historicamente sedimentado em torno do léxico "fuga" na língua portuguesa, que seria o seu "sentido", o qual passa a variar ou se desestabilizar de acordo com as sequências em que se insere - em que se acrescenta sua "força". Ou seja, não é que não exista um significado relativamente estabilizado nesse léxico e que tudo dependa do contexto; haveria, sim, um jogo tensivo entre estabilização / não estabilização, ou seja, entre o que estaria posto (embora de forma efêmera) e o que estaria em processo de criação (em estado de latência).

Sendo assim, uma possibilidade de tradução para dar conta, já a partir do título, do estilo musical polifônico da fuga e alavancar a cadeia de significações em que se insere o poema (e que, conforme sinalizarei adiante, se espraiará por outros itens lexicais), sem 
deixar que se perca na sequência "Fuga da morte", seria talvez "Morte em estilo fugal", ou mesmo simplesmente "Réquiem", modalidade musical que tematiza a morte e que pode vir a adquirir o formato de fuga, como acontece particularmente em Mozart. Notese, de resto, que também as propostas de Ascher ("Fuga fúnebre") e Cardozo ("Funesfuga") não são propícias a criar a ponte desejada, seja com termos como "Geigen" ou "Tanz", seja com itens condizentes com a estruturação do poema.

No caso da proposta tradutória mais corrente entre nós, "Fuga da morte", noto que, enquanto a língua alemã recorre à aglutinação para provocar o elo de regência entre os termos "Tod" e "Fuge", na língua portuguesa precisamos recorrer às preposições. Por um lado, é fato que, do ponto de vista lógico, a preposição "de" pode tanto abrir a possibilidade do adjunto adnominal com valor genitivo, quanto a possibilidade do complemento nominal. No primeiro caso, "fuga" poderia ser abordada do ponto de vista da modalidade musical, e "da morte" funcionaria como qualificativo (um tipo de fuga, ou o seu tema). No segundo, "da morte" teria um sentido causativo ou ablativo, ou seja, denotaria causa ou origem. Em função das cristalizações já existentes no termo "fuga", a proposta "Fuga da morte" tende a remeter ao ato de fugir. Contudo, o poema não tematiza uma fuga da morte nesse sentido que se constrói no título tal qual proposto pela maioria de nossos tradutores (inclusive Cavalvanti). Além disso, essa proposta tradutória despista ou apaga a possibilidade de enxergarmos o poema do ponto de vista musical e polifônico.

É neste ponto que teço uma segunda relação com as ideias defendidas por Meschonnic, que tanto condenou as traduções apagantes, particularmente aquelas que desconsideram o ritmo construído no poema e se detém nos significados presumidos em vocábulos isolados. O linguista francês nos chama a atenção para a panrítmica enquanto aspecto contínuo do poema, em contraposição aos elementos discretos ou isolados. O sentido ou a significação do poema seriam resultantes dessa panrítimica enquanto portadora da força de linguagem. O poema em pauta é, por isso mesmo, bastante ilustrativo dessa questão, mesmo por se tratar de poema que se constrói à moda de um réquiem no estilo da fuga.

Enfatizo, mais uma vez, a sutileza inerente à questão a que busco dar destaque, já que, à sua maneira, esta também implica uma tradução, ou seja, a forma com que o poema traduz para a rítmica que lhe é própria algo que pertence ao universo musical, não porque a declamação do poema imitaria certa sonoridade presente no estilo musical da fuga, mas 
porque, com seus próprios recursos, que são recursos linguístico-discursivos, o poeta constrói uma fuga poemática, em que certos versos deslizam de seu posicionamento previsto à medida que se repetem. É o que presenciamos, por exemplo, no seguinte excerto:

wir schaufeln ein Grab in den Lüften da liegt man nicht eng

Ein Mann wohnt im Haus der spielt mit den Schlangen der schreibt

der schreibt wenn es dunkelt nach Deutschland

(CELAN 1996b: 14).

São dignos de nota, no caso em pauta:

(a) a aparente ruptura sintática na transição do primeiro para o segundo verso, provocada pelos fenômenos de repetição e deslocamento, já que, em termos estruturais, "Ein Mann wohnt" retoma, de forma invertida e espelhada, "da liegt man";

(b) a retomada, em fuga, da sequência "der schreibt", que fecha o segundo verso e abre o terceiro.

É fato, lembremos, que ao aludir insistentemente à importância de nos determos no ritmo, particularmente no caso das traduções, para que não resultem apagantes, Meschonnic nos lembra da diferença existente entre o ritmo da poesia e aquele da música, mais uma razão para que "Todesfuge" se apresente para nós de forma ilustrativa e significativa, já que não se trata, afinal, de uma fuga musical, mas de um poema construído à moda da fuga. Fuga que, ao remeter à música, não se realiza, no entanto, musicalmente. No caso do poema, são as repetições de frases e palavras, as assonâncias e aliterações, as rupturas semânticas e sintáticas, o descompasso entre versos longos e curtos, a ausência de rimas e a falta de uniformidade nas estrofes, que constroem certa panrítmica responsável pelo "dixit" do poema, por seu acabamento, i.e., pela forma com que se dirige a nós (ou contra nós), e espera de nós uma resposta, ou, ainda, nos envolve, chamando-nos a participar do coro, do réquiem, de seu choro e de sua denúncia.

De resto, reside no âmago do ritmo a questão da subjetivação da linguagem, que Meschonnic extrai de postulações do linguista francês Émile Benveniste em torno da subjetividade na linguagem, e desenvolve. Trata-se da apropriação de uma linguagem e de sua subjetivação - mas o que seria isso? Em grande parte, o capítulo "O aparelho formal da enunciação” (BENVENISTE 1989) nos traz esclarecimentos a esse respeito, desde que não o leiamos à moda do signo, ou seja, na linha do estruturalismo que tende, 
neste caso específico, a discretizar sempre os conceitos, atribuindo-lhes um viés algorítimico e não criativo ou heurístico.

Postulações de Celan (1996a: 51), em “O Meridiano”, esclarecem-nos, de toda forma, esta questão da subjetivação, ao nos remeter à necessidade de um estranhamento: "A arte provoca um distanciamento do Eu. A arte exige aqui, numa direcção determinada, uma determinada distância, um determinado caminho". Esclarecem-nos ao nos apontar, indiretamente, que não se trata, no caso, do Sujeito histórico, ou filosófico, ou psicanalítico (conforme, aliás, nos assevera Meschonnic, 1989), mas do sujeito do poema, que se constrói a partir de um “distanciamento do Eu”. O poeta completa:

Talvez a poesia - é apenas uma pergunta - talvez a poesia, tal como a arte, se dirija, com um Eu esquecido de si, para aquelas coisas inquietantes e estranhas, para de novo se libertar - mas aonde? mas em que lugar? mas com que meios? mas em que condição? (CELAN 1996a: 51).

Vale lembrar, aqui, da ascendência dessas ideias aos poetas românticos alemães, e a Novalis em particular. Vale lembrar ainda da forma com que Meschonnic (2005: 5152) diferencia a noção de ritmo - com a subjetivação que lhe é própria - da noção de estilo: "Pois a noção de estilo é tudo o que a noção de signo permite pensar sobre uma atividade que lhe escapa e que ele não concebe senão pelo aspecto do esquema sentido/forma, enquanto não se trata de um esquema, mas do ritmo".

\section{4 É preciso escutar as palavras}

Acredito ser fundamental que o título - tal qual acontece no original - nos remeta à rítmica da fuga, tematizando não a fuga da morte (ou não apenas ela), mas o jogo de vozes que se seguirá: o título nos anuncia, no caso, o coro de vozes que está por vir, e nos sensibiliza para que possamos escutá-las. Mais uma vez, lembro de Meschonnic: é preciso que nos coloquemos na posição de escuta, é necessário calar as palavras para escutar a festa que celebram entre si: "Il faut arriver à faire taire les mots/ pour commencer à entendre/ les fêtes qui se célèbrent entre eux" (MESCHONNIC 1999a: 45).

Celan (1996a: 43), por sua parte, poderá dizer em “O Meridiano”, datado de 1960: "Para ser mais exacto: alguém que ouve e escuta e olha ... e depois não sabe do que se esteve a falar". 
Acredito que, no caso de "Todesfuge", a escuta desprovida do título e do ritmo que desencadeia pode nos dar a impressão apenas de frases truncadas, incompletas, ou que se completam de forma estranha. No entanto, o fato de sabermos que o poeta trata de compor os versos no estilo musical da fuga - musical que, no caso, se traduz em frases descontinuadas à moda de vozes que se interpelam, ou se atravessam, ou se sobrepõem fornece-nos uma chave importante de leitura, mesmo porque sabemos que esse estilo foi explorado por Mozart, por exemplo, para a composição do réquiem.

Meschonnic insiste, conforme já apontei de início, tanto em sua obra ensaística, como na poética, na importância da presença do diálogo, no sentido de que toda linguagem se faz necessariamente como diálogo (algo que pode parecer óbvio, ou banal, mas para cuja verdade nem sempre estamos plenamente sensíveis), e de que é na linguagem poética que esse fenômeno se presentifica de forma mais intensa ou exacerbada. Esta postulação é necessariamente trazida para a tradução, na qual o ritmo do oral / da oralidade (enquanto presença do diálogo com um Outro, i.e., a interpelação do Outro no poema) precisa se reconstruir sob pena do apagamento dos aspectos ético e estético presentes no âmbito do poético. Celan tratará dessa questão nestes termos, que até parecem ter sido pensados em torno de "Todesfuge":

O poema torna-se - e em que condições! - o poema de um sujeito que insiste em ser um sujeito de percepção, atento a todos os fenómenos, e interrogando e apostrofando esses fenómenos: e torna-se diálogo, muitas vezes um diálogo desesperado (CELAN 1996a: $57)$.

De toda forma, se até agora apontei para uma dificuldade e especificidade da língua portuguesa na tradução do título, por outro lado, é interessante notar a fertilidade da língua portuguesa nesse aspecto, já que a ideia da fuga e da caça, conforme destaquei acima, estaria presente de alguma forma na origem latina da terminologia musical, talvez relativamente esquecida em outros idiomas, como seria o caso do alemão. Esclareço: cabe notar que pela língua portuguesa podemos trazer à tona a complexidade já existente no título em alemão, possivelmente nem sempre visível para o próprio leitor alemão.

O poeta explora em sua proposta de escrita duas questões já implícitas no título que atribui ao poema: por um lado, aquela da morte iminente, em que há o algoz e os cães e, portanto, há a ideia de caça e de fuga em latência (ambas presentes na etimologia do termo musical); por outro lado, na distribuição diagramática, as vozes se presentificam em fuga, ou seja, em alternância, em repetição e retomada de um tema. Conforme 
podemos ler neste trecho: "er pfeift seine Rüden herbei/ er pfeift seine Juden hervor läßt schaufeln ein Grab in der Erde/ er befiehlt uns spielt auf nun zum Tanz" (CELAN 1996b: 14).

Sendo assim, a ambiguidade do termo "fuga" na língua portuguesa torna-se, em alguma medida, propícia à tradução, podendo-se detectar certa inversão em relação à presença da memória em cada uma das línguas: na língua alemã, o sentido de "esquiva" encontra-se relativamente esquecido dentro do passado remoto a que o termo remete em sua origem latina; na língua portuguesa é o sentido musical, por pouco usual ou restrito a certo público, que se encontra em estado de latência.

\section{A tradução enquanto crítica, e a crítica do ritmo}

Avancemos rumo às postulações de Meschonnic - mas também de Haroldo de Campos da tradução enquanto crítica, e, no caso mais específico do poeta francês, da crítica do ritmo que se faz, em parte, de forma ensaística, em parte, pela própria experimentação da tradução e, de resto, na atuação dessas duas atividades de forma complementar.

"Critique du rythme", como crítica do ritmo e sobre o ritmo, crítica que, ao se dirigir ao ritmo, trata de reconstrui-lo, de recolocá-lo no lugar que lhe seria devido, não à moda da métrica, enquanto discretização ou quadratura, mas à moda do movimento, das ondulações, da discursividade.

No decorrer de "Todesfuge" há a referência a sonoridades diversas mescladas com elementos próprios ao estilo musical da fuga, como a alusão à presença dos violinos: sabemos que o algoz de olhos azuis apita para seus cães, ordena aos judeus que toquem a dança da morte, grita para que arranquem sons escuros dos violinos. Ou seja, o poeta insere no poema alguns elementos que confirmam ou reafirmam, isotópica ou metonimicamente, a chamada contida no título. Chamar a atenção para esses aspectos, no entanto, não seria suficiente para contemplar aquilo a que Meschonnic nos conclama algo precisa comparecer na própria rítmica construída no poema, a qual, por sua vez, se faz de assonâncias, aliterações, elisões e truncamentos, sons, cadências, alternâncias e silêncios. 
CINTRA MARTINS, M. - Em torno de "Todesfuge" de Paul Celan

Pensando-se na complexidade da tradução em vista de todas essas nuances, podemos dizer, por exemplo, que talvez Barrento não devesse, na passagem do quarto para o quinto verso, acima mencionado, antecipar o adjunto adverbial "na casa" - em “cavamos um túmulo nos ares aí não fícamos apertados/ Na casa vive um homem que brinca com serpentes escreve" - já que ao fazer isso contribuiu para evitar a ruptura lógica existente no poema alemão ("wir schaufeln ein Grab in den Lüften da liegt man nicht eng/ Ein Mann wohnt im Haus der spielt mit den Schlangen der schreibt” (CELAN 1996b: 14).

Entretanto, conforme nos alerta Ataíde (2011), há uma dificuldade enorme na tradução em função da necessidade de se dar conta, por um lado, do aspecto sintático/sintagmático e lógico presente no poema, por outro, de sua cadência rítmica. Nesse sentido, tal qual Derrida (e não da forma austera que Meschonnic assume em sua crítica), Ataíde pondera que as diferentes traduções completam lacunas e oferecem, cada uma a sua moda, oportunidades de se enxergarem diferentes perspectivas presentes no texto original.

Quanto às traduções de poemas de Paul Celan para o francês, Meschonnic publicou, em 1972, dois anos após a morte do poeta alemão, na revista "Cahier $d u$ Chemin", uma crítica contundente, posteriormente incorporada em "Poétique $d u$ Traduire II", em que destaca o aspecto apagante dessas traduções que desenraizariam historicamente seus poemas em função do ensejo de torná-los mais legíveis ou menos herméticos. A propósito, Celan se oporia no diálogo com a língua corrente alemã a seu funcionamento convencional. Segundo o crítico francês, o hermetismo de Celan estaria diretamente relacionado com o holocausto, e não com certa leitura ornamental da obra de Mallarmé que teria servido como pauta para tradutores como André du Bouchet.

Eis mais um aspecto importante da teorização de Meschonnic, aquele da relação entre a língua em seu uso mais convencional e na escritura - e que se associa, de resto, à questão rítmica, comportando mais uma dificuldade para a tradução. Ataíde (2011) cita a menção de Horn (2011) ao vínculo existente entre o primeiro verso do poema de Celan (i.e. "Schwarze Milch der Frühe wir trinken sie abends") e o ditado da tradição oral judaica "se todos na infelicidade vivem, Mordechai Meisel se banha no leite branco do alvorecer”, em que haveria a alusão do que seria um homem de sorte. Já no romance “Imago”, do escritor suíço Carl Spitteler, datado de 1906, encontramos alusão à canção 
popular "Am Morgen in der Frühe, da melken wir die Kühe” ("De manhã, de madrugada, então tiramos leite - ordenhamos - [d]as vacas").

Não podemos negligenciar, aliás, a forma de diálogo do próprio Meschonnic poeta com os provérbios e ditos populares, já desde "Dédicaces proverbes", datado de 1972, em que seus poemas dialogam temática e ritmicamente com provérbios e falas proverbiais e também comportam o diálogo com a fala cotidiana, ou seja, com a assim chamada "linguagem ordinária", lembrando-nos de que o poeta francês via na própria literatura a prova de que não existe isso que costumamos chamar de "linguagem ordinária" (ou "linguagem do cotidiano"). Pela literatura, toda linguagem seria ordinária, pois, se a poesia é a revelação do ritmo como tal, como o rio da linguagem com que um sujeito se identifica momentaneamente, ela própria faria essa noção de linguagem ordinária voltarse contra si mesma. Deixando a linguagem de domingo aos padres, que eles dirigem a si próprios, a poesia, aquém e além da oposição entre o verso e a prosa, toma a linguagem ordinária e mostra que toda linguagem é ordinária, e que ela própria surge daí: "Ela é o ato pelo qual o ordinário se descobre toda a linguagem. E é, então, através da poesia que não há mais linguagem ordinária” (MESCHONNIC 2006:14).

No caso de "Todesfuge", podemos dizer que o poema de Celan dialoga tanto com o léxico, quanto com a sintaxe convencional da língua alemã, subvertendo-o. Nas diversas traduções listadas por Ataíde, há a atenção de se manter as rupturas sintáticas, porém, conforme alerta o estudioso, excetuando-se a tradução de Suttana, de forma geral não teria sido dada a devida atenção ao ritmo, que teria uma cadência ternária constante no original alemão, gerando o efeito hipnótico de transe. Ou seja, neste caso, temos duas questões que se sobrepõem: uma que diz respeito à rítmica da língua alemã, assim como a sua subversão pelo poeta, e que se realiza através de elisões e rupturas sintáticas; outra que diz respeito à composição da fuga e dos enunciados que se retomam, em que Ataíde (2011) destacou a cadência ternária.

Sem se referir a Celan, Meschonnic pondera em sua "Poética do Traduzir":

Se um grupo rítmico é um grupo de sentido, as separações instalam um conflito entre grupo sintático e grupo de sentido. O "sentido" oscila entre a sintaxe e o ritmo. Mas o ritmo prima, porque ele separa, contra a sintaxe que liga as preposições a seu substantivo, e os elementos entre eles de um sintagma nominal. Ora, o ritmo não muda nada no sentido lexical. Se ele muda alguma coisa, e muda necessariamente alguma coisa, já que tudo que chega ao discurso modifica o discurso, isto só pode ser no modo de significar. [...] As 
próprias condições da enunciação transformam a significação (não o sentido) do enunciado (MESCHONNIC 1999b: 48-49).

Da minha parte, entendo que, se há modificação sobre a significação, esta se espraia, mesmo que efemeramente, sobre o sentido. Ou seja, naquele momento, determinado léxico (que guardava, historicamente, certo sentido) passa a ser contagiado pela forma de significação que lhe é traduzida pelo ritmo, i.e., pela força da linguagem. Uma nova História se inaugura.

\section{A fuga e a escrita anagramática}

Meschonnic nos alerta seguidamente para o ritmo, a força da linguagem, o processo de subjetivação e a atenção ao contínuo da enunciação em detrimento da discretização da linguagem. Na linha do pensamento de Émile Benveniste, e radicalizando-o, combate a abordagem semiótica da linguagem, e defende a consideração do discurso, da enunciação, da significação. Também trata de recuperar para nós a leitura de um Ferdinand de Saussure das continuidades - ou seja, portador de um enfoque contínuo, e não discreto da linguagem -, que, segundo ele, teria apontado para a relevância do poético, sem, no entanto, desenvolvê-la. Um Saussure que teria desenhado a língua de um ponto de vista dinâmico e criativo, diferentemente da leitura que o Estruturalismo nos proporcionou dele.

Há ainda o Saussure dos anagramas, mas quem se detém neste é o poeta, teórico e tradutor brasileiro Haroldo de Campos (2013), em suas cogitações em torno da linearidade, ou não, do signo linguístico, e da forma com que essas questões compareceram na teorização saussureana. O Saussure dos anagramas foi trazido à tona no momento em que o "Curso de Linguística Geral” já era amplamente conhecido, traduzido e vulgarizado dentro de uma visada estruturalista. A obra foi publicada no Brasil em 1974 (STAROBINSKI 1974). Foi no estudo do verso saturnino, que Saussure identificou, primeiro, palavras que se formariam em sequência não linear, como que cifradas no decorrer de determinados versos. Depois, seja como anagramas, hipogramas ou paragramas, reconheceu-as, também, em cantos védicos e na antiga poesia germânica aliterante. Conforme nos explica Campos:

O ponto nodal das reflexões de Saussure sobre os fenômenos anagramáticos está, justamente, naquilo em que elas tocam a questão da linearidade da língua. Trata-se, como 
diz Starobinski, da questão do tempo na linguagem, que, por força do anagrama, surge a uma nova luz, quando os fonemas da palavra-tema são deslocados da ordem que lhes é própria, passando a sofrer um tratamento fugal (CAMPOS 2013: 116).

A concepção da escrita, e da escritura em particular, como partitura - ou seja, de forma não linear -, se já praticada por poetas, teria vindo à tona por meio de Jacques Lacan, que refutou, ao menos em parte e antes de conhecer suas ideias das palavras sob as palavras, a tese saussureana da linearidade do signo linguístico, ou seja, "bastaria escutar a poesia [...] para ouvir como emerge uma verdadeira polifonia, para saber que de fato todo discurso alinha-se nas várias pautas de uma partitura", diria Lacan retomado por Campos (2013: 111).

Trata-se, seja como for, de fenômenos que se dão paralela ou complementarmente: aquele que Saussure desvendou, de certas palavras que se encontram cifradas e distribuídas de forma descontínua na continuidade de determinados versos e estrofes, e este, da configuração da poesia à moda de uma partitura, propícia à declamação ou leitura simultânea, i.e., em "textos destinados a uma leitura não linear, mas plúrima" (CAMPOS 2013: 118).

Por sua vez, a fuga enquanto estilo musical polifônico, contrapontista e imitativo, teve origem no barroco. Várias vozes entram sucessivamente e vão se entrelaçando na medida do andamento musical. No caso do "Réquiem em ré menor", composto por Mozart em 1791, é inserido, após o Introito e o Kyrie, parte do hino "Dies Irae”, do século XIII, de provável origem bíblica e de métrica trocaica (na alternância de tônica/átona):

\section{Dies Irae}

Dies irae, dies illa

Solvet saeclum in favilla

Teste David cum Sibylla

Quantus tremor est futurus

Quando judex est venturus

Cuncta stricte discussurus! ${ }^{2}$

Tema retomado na famosa sequência "Lacrimosa", da mesma composição musical:

\footnotetext{
${ }^{2}$ Que, no entanto, traduzo sem seguir a métrica trocaica: "Dia de Ira: Dia de ira, aquele dia/ Vão-se os séculos em cinzas/ Atestam Davi e Sibilal Quanto tremor 'inda há de vir/ Quando chegar o Juiz/ Com sentença toda estrita". 
CINTRA MARTINS, M. - Em torno de "Todesfuge" de Paul Celan

\author{
Lacrimosa \\ Lacrimosa dies illa \\ qua resurget ex favilla \\ Judicandus homo reus \\ Huic ergo parce, Deus \\ Pie Jesu Domine \\ Dona eis requiem, Amen ${ }^{3}$
}

O fato é que, conforme nos aponta Ataíde (2011) na referência ao "Todesfuge”, “com a exceção do segmento 'Schwarze Milch der Frühe', que corresponde a uma sequência de três pés trocaicos $\left(-_{-} /-_{-} /{ }_{-}\right)$, cada um dos segmentos que formam o poema se constitui de uma sequência de anfíbracos", i.e., de sequências ternárias. Não fosse a temática de que o poeta trata, poderíamos não dar atenção especial à presença da métrica trocaica no primeiro verso - que se repete três vezes no decorrer do poema; não fosse o título "Todesfuge”, também a lembrança de "Dies Irae”, em sua métrica trocaica, não se faria tão facilmente presente.

Com isso temos, além do fenômeno polifônico das palavras sob as palavras, a transposição para a arte poética de uma forma de (re) distribuição e retomada de versos, ou parte deles, em que palavras de um tema que se propõe na primeira estrofe sofrem variações e deslocamentos dentro de um tratamento fugal a tal ponto sutil, que não se transformam em artifício, mas se dá a entrever em sua tonalidade sugestiva. Forma e conteúdo amalgamam-se, já que aquilo de que se trata, ou seja, o terrível genocídio em campos de concentração, é apresentado à maneira do réquiem, remetendo-nos ainda a diversos aspectos biográficos que sabemos presentes na vida do poeta, mesmo aquele, posterior ao poema em questão, de um encontro mal resolvido com Heidegger para o qual o poeta teria esperado a retratação do filósofo.

Celan esperava que, no encontro entre ambos em uma cabana na Floresta Negra, em 1967, Heidegger manifestasse seu desejo de pedir perdão por seu posicionamento político a favor do nazismo, mas isso não aconteceu. Em carta datada de poucos meses antes de seu suicídio, e que seria enviada ao filósofo, Celan teria escrito “[...] pelo vosso

\footnotetext{
${ }^{3}$ Que também traduzo sem seguir a métrica trocaica: "Lacrimoso: Lacrimoso aquele dia/ Quando ressurge das cinzas/O homem réu a ser julgado/Dele pois piedade, Deus/Piedoso, Senhor Jesus/Dai-lhe descanso, Amém".
} 
comportamento enfraqueceis de maneira decisiva o poético e ouso suspeitá-lo o filosófico na vontade séria de responsabilidade que pertence a ambos". ${ }^{4}$

É nesse ponto que retomo, de forma sintética, duas questões da teorização meschonniciana, as quais se interligam à sua maneira: o combate à métrica e a defesa da união entre Ética, Poética e Política, por meio da presença do corpo na linguagem.

\section{7 À guisa de conclusão}

Encontramos no combate mechonniciano à prevalência da métrica nos estudos linguísticos e literários sua afinidade com as ideias pronunciadas por Paul Celan em " $O$ Meridiano”, onde este se contrapõe a uma arte construída por meio de artifícios, e aponta, à sua maneira, e de forma sintética e alusiva, a ligação íntima que se constrói entre Ética, Estética e Política, de um ponto de vista interno à arte:

Poesia: é qualquer coisa que pode significar uma mudança na respiração. [...] Talvez aqui, com o Eu - este Eu surpreendido e liberto aqui e deste modo -, talvez aqui se liberte ainda um Outro. Talvez o poema seja ele próprio a partir deste ponto ... e possa agora, deste modo não artístico e liberto da arte [i.e. dos artifícios], seguir os seus outros caminhos, e assim também os caminhos da arte [...] (CELAN 1996a: 54).

O poema liberto da arte é o poema liberto de artifícios e da métrica, no que esta poderia implicar artificialidade rítmica. No lugar do artificialismo e de sua aderência a modelos pré-existentes - ou a palavras que insistem em dominar nosso pensamento entra a poesia como possibilidade de libertação, e o pensamento como invenção do pensamento (MESCHONNIC 2005). Celan nos assevera: “Ampliar a arte? Não. Entra antes com a arte no que em ti próprio há de mais acanhado. E liberta-te" (CELAN 1996a: 59).

A poesia como mudança de respiração implica a presença do corpo na linguagem, assim como a união indissolúvel entre Ética, Poética e Política, centrada em um sujeito atento aos fenômenos, que os interroga e os apostrofa - e nos interroga, e nos interpela.

Se o ritmo é a própria presença do corpo na linguagem, é ele que atribui sentido às frases e palavras, ao lhes atribuir força e união. Para isso, o poema de Celan torna-se bastante ilustrativo, assim como a crítica a seu eventual hermetismo e a sua fragmentação. Sem a percepção do ritmo, afloram diante de nós frases truncadas e sem sentido aparente;

4 Informação disponível em <https://sites.google.com/site/incensuraveis/conversa-acabada--celanheidegger> Acesso em 05.05.18.

Pandaemonium, São Paulo, v. 22, n. 37, mai.-ago. 2019, p. 357-376 
podemos dizer que estamos diante de uma linguagem estilhaçada ou em ruínas, o que não deixa de ser uma das possibilidades de leitura diante do texto polifônico a que presenciamos. A percepção do ritmo e, no caso, da transposição do estilo musical da fuga para o poema, atribui sentido à eventual fragmentação e às ruínas. Não as justifica, faz com que se apresentem em sua força de linguagem - e de denúncia.

Neste trabalho, mesmo em função do espaço restrito, detive-me na sinalização da forma com que o ritmo se constrói em "Todesfuge" com recursos panrítmicos que se desencadeiam a partir do título e se sustentam, em parte em itens lexicais que confirmam a sugestão presente no título, em parte na configuração formal do poema. Chamo a atenção, entretanto, para o fato de que a forma, neste caso, não se presentifica apenas pela sonoridade deste ou daquele vocábulo, mas pela maneira de sua distribuição, que simula e retoma, em tradução, o estilo de repetição e deslocamento próprio da fuga musical. Dessa maneira, sem me voltar em particular para a questão bastante presente nos estudos literários a respeito do que uma obra significa, ou de qual a eventual mensagem que comporta, busco alertar para sua força de significação, ou seja, para a cadeia de sentido que o poema comporta, seguindo a linha do pensamento dos dois autores em que me centro. Inevitavelmente acabo aludindo à significação do poema como um todo, porém, sem apelar para uma eventual dicotomização entre significante e significado. Por isso mesmo, pode-se ter a impressão momentânea de que tratei apenas do título, quando, de fato, meu enfoque se espraiou pelo poema de forma mais geral.

Volto às primeiras palavras deste trabalho em que fiz menção ao pressuposto do diálogo enquanto interpelação do outro, mesmo porque é nele que reside o apelo à Ética em última instância (e lembrando-nos aqui, mais uma vez de Levinas). Lembre-se que, na teorização que tentamos compreender, cada visada se conecta com a outra: o combate ao signo envolve a defesa das continuidades, sendo que nelas reside a crítica do ritmo. $\mathrm{O}$ ritmo, por sua vez, só se dá como processo de subjetivação e como presença do outro na linguagem, i.e., como oralidade, como interpelação do outro nos interstícios do poema, de tal forma que "eu" e "outro" formam uma unidade, em confronto e em estado de complementariedade.

É dentro desse circuito, aberto e fechado, que encontramos - talvez de forma paradoxal, imprevista e, sobretudo, original - o elo que interliga internamente, no caso que venho tratando, Ética, Poética e Política, enquanto conduz à exigência da invenção 
constante do pensamento e da linguagem, do pensamento pela linguagem, do silenciar das palavras para que outras palavras possam ser escutadas.

Da renovação e da transformação da vida e da História por meio das palavras.

\section{Referências bibliográficas}

ANDRADE, Mário. Pequena História da Música. São Paulo: L. Martins Editora, 1944.

AtAíDE, Artur Almeida de. Todesfuge, de Paul Celan, e suas traduções. Cultura \& Tradução, v. 1, n. 1, 2011.

CAMPOS, Haroldo de. Diábolos no texto (Saussure e os anagramas). In: CAMPOS, Haroldo de. A reoperação do texto. São Paulo: Perspectiva, 2013.

Celan, Paul. Arte Poética: O Meridiano e outros textos. Lisboa: Cotovia, 1996a. . Sete Rosas Mais Tarde: Antologia Poética. Lisboa: Cotovia, 1996b.

BENVENISTE, Émile. O aparelho formal da enunciação. In: BENVENISTE, Émile. Problemas de Linguística Geral II. Campinas/SP: Pontes, 1989.

DERRIDA, Jacques. Schibboleth. Pour Paul Celan. Paris: Galillée, 1986.

GOETHE, Johann Wolfgang von. Fausto. São Paulo: EDUSP, 1981.

HORN, Erich. Paul Celan: die Todesfuge - eine multimeidiale Annäherung. 2011. Disponível em: <www.celan-projekt.de> Acesso em 07.07.2018.

LEVINAS, Emmanuel. Totalité et infini. Essai sur l'extériorité. Paris: Kluwer Academic, 2017.

Meschonnic, Henri. Dédicaces proverbes. Gallimard, 1972.

. Critique du rythme: anthropologie historique du language. Paris: Verdier, 1982.

. La rime et la vie. Lagrasse: Verdier, 1989.

. Combien de noms. Paris: L'Improviste, 1999a.

. Poética do Traduzir. São Paulo: Perspectiva, 1999b.

. La force du langage. In: CHISS, Jean-Louis; DESSONS, Gérard (Ed.). La force du langage. Rythme, discours, traduction. Autour de l'oeuvre d'Henri Meschonnic. Paris: Honoré Champion, 2000.

. Oui, qu'appelle-t-on penser?" In: Dessons, Gérard; MARTIN, Serge; MichON, Pascal. Henri Meschon nic, la pensée et le poème. Paris: In Press, 2005.

Linguagem, ritmo e vida. Belo Horizonte: FALE/UFMG, 2006.

. Dans le bois de la langue. Paris: Éditions Laurence Teper, 2008.

STAROBINSKI, Jean. As palavras sob as palavras. São Paulo: Perspectiva, 1974.

Recebido em 07 de julho de 2018 Aceito em 20 de novembro de 2018 